\title{
AMPLIFIKASI DNA ALGA MERAH (RHODOPHYTA) Eucheuma sp.
}

\author{
Paratiti Dewi Djakatara ${ }^{1}$, Grevo S. Gerung ${ }^{2}$, Elvy L. Ginting ${ }^{2}$, \\ Calvyn F.A. Sondak ${ }^{2}$, Natalie D.C. Rumampuk ${ }^{2}$, Desy M.H. Mantiri ${ }^{2}$ \\ ${ }^{1)}$ Program Studi Ilmu Kelautan, Fakultas Perikanan dan Ilmu Kelautan, \\ Universitas Sam Ratulangi, Manado. \\ ${ }^{2)}$ Program Studi Manajemen Sumberdaya Perairan, Fakultas Perikanan dan IImu Kelautan, \\ Universitas Sam Ratulangi, Manado. \\ E-mail: dewi.djakatara@gmail.com
}

\begin{abstract}
ABSTRAK
Indonesia is a rich source of biodiversity and having a richness species of marine organisms. Indonesia has around 17,000 islands, a suitable place for seaweed growth because of its long coastline. There are around 782 species of seaweed in Indonesia with 196 species of green algae, 134 species of brown algae, and 452 red algae. Any of various seaweeds that potential sources of revenue and mostly can be found around Indonesian waters is Eucheuma $\mathrm{sp}$. including in red algae and can produce carrageenan. Algae Morphological characteristics can be influenced by environmental factors among others: water movement, sunlight, temperature, salinity, and degree of acidity $(\mathrm{pH})$. Beside environmental factors, genetic factors can influence differences in production quality and morphological characteristics of algae. To distinguish morphological characteristics can be analyzed molecularly. In molecular analysis, important steps that must be taken are DNA isolation and genomic DNA amplification. Isolation of red algae DNA in this study using the CTAB method which was modified from Doyle and Doyle (1987), Allen (2006) and Nugroho et al. (2015). Amplification of red algae genomic DNA (Eucheuma sp.) Using COX2 and $r b c L$ genes on PCR. The success of the genomic DNA isolation process and the amplification of COX2 and rbcL genes from Eucheuma sp. detected through UV transilluminator after going through a gel electrophoresis process. Based on this study, several modifications need to be carried out in the DNA isolation stage Eucheuma sp. by using the method of Doyle and Doyle (1987) modifications that need to be carried out include adding vitamin $\mathrm{C}$ and liquid nitrogen. Furthermore DNA of Eucheuma sp. successfully amplified by using F-577 and R-753 primers.
\end{abstract}

Keywords : Seaweed, Eucheuma sp., Extraction, DNA, CTAB

Indonesia merupakan negara yang kaya akan sumber keanekaragaman hayati dan memiliki kekayaan spesies laut tertinggi. Indonesia memiliki sekitar 17.000 pulau, menjadi tempat yang cocok untuk pertumbuhan rumput laut karena garis pantainya yang panjang. Terdapat sekitar 782 spesies rumput laut di Indonesia dengan 196 spesies alga hijau, 134 spesies alga cokelat, dan 452 alga merah. Salah satu jenis rumput laut yang potensial dan banyak dijumpai di perairan Indonesia adalah Eucheuma sp. yang termasuk dalam alga merah dan dapat menghasilkan karaginan. Karakteristik morfologi alga dapat dipengaruhi oleh faktor lingkungan antara lain : gerakan air, cahaya matahari, suhu, salinitas dan derajat keasaman $(\mathrm{pH})$. Selain faktor lingkungan, faktor genetik dapat mempengaruhi perbedaan kualitas produksi dan karakteristik morfologi pada alga. Untuk membedakan karakteristik morfologi dapat dianalisis secara molekuler. Dalam analisis molekuler, langkah penting yang harus dilakukan adalah isolasi DNA dan amplifikasi DNA genomik. Isolasi DNA alga merah dalam penelitian ini menggunakan metode CTAB yang di modifikasi dari Doyle dan Doyle, (1987), Allen, (2006) dan Nugroho $d k k$, (2015). Amplifikasi DNA genomik alga merah (Eucheuma sp.) menggunakan gen COX2 dan rbcL pada PCR. Keberhasilan proses isolasi DNA genomik dan amplifikasi gen COX2 dan rbcL dari Eucheuma sp. dideteksi melalui UV transilluminator setelah melalui proses elektroforesis gel. Berdasarkan penelitian ini, beberapa modifikasi perlu dilaksanakan dalam tahap isolasi DNA Eucheuma sp. dengan menggunakan metode Doyle dan Doyle, (1987) modifikasi yang perlu dilaksanakan meliputi penambahan vitamin $C$ dan nitrogen cair. Selanjutnya DNA Eucheuma sp. berhasil diamplifikasi dengan menggunakan primer F-577 dan R-753.

Kata kunci: Rumput Laut, Eucheuma sp., Ekstraksi, DNA, CTAB 


\section{PENDAHULUAN}

Indonesia merupakan negara yang kaya akan sumber keanekaragaman hayati dan memiliki kekayaan spesies laut tertinggi. Indonesia memiliki sekitar 17.000 pulau, menjadi tempat yang cocok untuk pertumbuhan rumput laut karena garis pantainya yang panjang (Gerung, 2001). Melalui ekspedisi Siboga, terdapat sekitar 782 spesies rumput laut di Indonesia dengan 196 spesies alga hijau, 134 spesies alga cokelat, dan 452 alga merah (Amaranggana dan Nasrul, 2017). Rumput laut tumbuh di alam dengan melekatkan dirinya pada karang, lumpur pasir, batu, dan benda keras lainnya (Anggadiredja $d k k ., 2010)$.

Salah satu jenis rumput laut yang potensial dan banyak dijumpai di perairan Indonesia adalah Eucheuma sp. yang termasuk dalam alga merah dan dapat menghasilkan karaginan. Karaginan adalah campuran yang kompleks dari beberapa polisakarida. Ada tiga jenis karaginan, yaitu lambda, kappa dan iota (Hudha dkk., 2012).

Karakteristik morfologi alga dapat dipengaruhi oleh faktor lingkungan antara lain: gerakan air, cahaya matahari, suhu, salinitas dan derajat keasaman $(\mathrm{pH})$. Selain faktor lingkungan, faktor genetik juga dapat mempengaruhi perbedaan kualitas produksi dan karakteristik morfologi pada alga. Untuk mengetahui karakteristik genetik dari jenis alga dapat dilakukan dengan analisis molekuler DNA. Perbedaan genetik dari masing-masing jenis alga dapat dijadikan bibit untuk pengembangan budidaya alga selanjutnya (Tenriulo dkk., 2001). Teknik konvensional sering kurang maksimal digunakan dalam identifikasi spesies, bahkan pada kasus-kasus tertentu banyak menimbulkan kekeliruan sehubungan dengan tingkat plastisitas morfologi yang tinggi dari jenis alga ini (Zuccarello $d k k$., 2006). Pada metode lain yang berbeda, pengaplikasian teknik molekuler pada alga masih memiliki banyak kesulitan terutama dalam mendapatkan jumlah dan kualitas DNA maupun hasil amplifikasi gen target yang ideal untuk analisis molekuler selanjutnya (Anggraeni et al., 2008).

Adapun tujuan dari penelitian ini adalah menentukan keberhasilan ekstraksi DNA rumput laut Eucheuma sp. menggunakan metode CTAB yang dimodifikasi dan mengamplifikasi gen COX2 dan gen rcbL sebagai gen target identifikasi rumput laut Eucheuma sp. dengan menggunakan beberapa kombinasi pasangan primer.

\section{METODE PELAKSANAAN}

\section{Tempat dan Waktu Penelitian}

Penelitian dilaksanakan pada bulan Mei sampai Juli 2018. Sampel alga yang digunakan yaitu jenis Eucheuma sp. yang telah tersimpan di Laboratorium Biologi Molekuler dan Farmasiteka Laut Universitas Sam Ratulangi Manado.

\section{Ekstraksi DNA Eucheuma sp. \\ 1. Extraction Buffer}

Proses pembuatan extraction buffer yaitu, $1 \mathrm{M}$ Tris, $5 \mathrm{M} \mathrm{NaOH}$, 0,5M EDTA, 5M $\mathrm{NaCl}$, TE Buffer, 3M NaAc, CTAB, dH2O, PVP, $\beta$-mercaptoetanol, vitamin $C$.

\section{Lisis Sel}

Sampel rumput laut dipotong hingga mendapatkan berat sampel sebanyak 0,10 g. Kemudian sampel digerus dengan nitrogen cair menggunakan mortar dan pestel steril. Sampel hasil gerusan kemudian dipindahkan ke tube lalu tambahkan Extraction buffer sebanyak 1 $\mathrm{ml}$.

\section{Ekstraksi DNA}

Sampel kemudian diinkubasi pada suhu $65^{\circ} \mathrm{C}$ selama 5 jam. selanjutnya disentrifugasi selama 4 menit pada kecepatan $12.000 \mathrm{rpm}$. Proses ini diulang sebanyak 6 kali dan untuk pengulangan terakhir supernatan tidak dibuang.

\section{Presipitasi}

Lapisan atas dipindahkan ke tube dan ditambahkan Fenol-Chloroform-Isoamyl Alkohol dengan perbandingan 25:24:1 sebanyak $800 \mu \mathrm{l}$ lalu diinkubasi selama 30 menit pada suhu ruangan $\left( \pm 25^{\circ} \mathrm{C}\right)$. Selanjutnya disentrifugasi selama 10 menit dengan kecepatan 13.500 g. Setelah terbentuk tiga lapisan, lapisan supernatan pada bagian paling atas dipindahkan ke tube dan ditambahkan 2-propanol dingin sebanyak $800 \mu \mathrm{l}$ dan dicampurkan dengan cara membolak-balik tube secara perlahan, 
lebih lanjut disimpan di Laminar Air Flow selama 10 menit pada suhu ruangan $\left( \pm 25^{\circ} \mathrm{C}\right)$, dan disentrifugasi dengan kecepatan $13.500 \mathrm{~g}$ selama 10 menit kemudian supernatan dibuang.

TE Buffer sebanyak $250 \mu \mathrm{l}$ ditambahkan ke tube lalu diinkubasi dalam termoblok selama 30 menit pada suhu $37^{\circ} \mathrm{C}$. Selanjutnya $3 \mathrm{M} \mathrm{NaAc}$ sebanyak 25 $\mu l$ ditambahkan ke tube kemudian dicampurkan dengan menginvert tube.

\section{Purifikasi}

Etanol dingin $70 \%$ sebanyak $600 \mu \mathrm{l}$ ditambahkan ke dalam tube dan invert sebanyak satu kali. Inkubasi dalam Laminar Air Flow selama 10 menit pada suhu ruangan $\left( \pm 25^{\circ} \mathrm{C}\right)$ lalu sentrifugasi dengan kecepatan $13.500 \mathrm{~g}$ selama 10 menit kemudian supernatan dibuang. Etanol dingin $90 \%$ sebanyak $500 \mu$ l ditambahkan ke tube, kemudian tube disentrifugasi dengan kecepatan $13.500 \mathrm{~g}$ selama 10 menit dan supernatan dibuang. Presipitan yang didapatkan kemudian dikeringkan dalam Laminar Air Flow dengan cara meletakkan tissue. Tube dibuka dan kemudian dibalik dan didiamkan selama 2 jam. TE Buffer sebanyak $25 \mu$ d ditambahkan ke dalam tube. Sampel dapat disimpan dalam kulkas sebelum digunakan untuk digunakan dalam proses selanjutnya.

\section{Elektroforesis Gel}

\section{Pembuatan Gel Agarose}

Gel agarose $1 \%$ dibuat dengan melarutkan $0,3 \mathrm{gr}$ bubuk agarose, $30 \mathrm{ml}$ 10x TBE buffer yang didihkan, selanjutnya di diamkan selama 10 menit dan ditambahkan 0,6 $\mu \mathrm{l}$ cyber green DMSO kemudian dituangkan ke dalam cetakan gel tray dan biarkan selama \pm 30 menit hingga mengeras menjadi gel.

\section{Elektroforesis Gel}

Proses elektroforesis dilakukan dengan mencampurkan sebanyak $4 \mu$ DNA sampel dengan $1 \mu \mathrm{l} 10 \mathrm{x}$ Sampel Loading Buffer di atas parafilm, kemudian dimasukan ke dalam sumur gel elektroforesis. Sebanyak $2 \mu \mathrm{l}$ 100bp ladder DNA marker dimasukan pula ke dalam sumur gel elektroforesis yang berbeda sebagai penanda berat molekul. Proses elektroforesis dilakukan menggunakan larutan $1 \mathrm{x}$ TBE buffer dengan tegangan listrik 80 volt selama 30 menit.

\section{Visualisai dengan UV- Transilluminator \\ Setelah proses elektroforesis} selesai, gel kemudian diangkat dan letakkan di atas UV-transilluminator untuk diamati keberadaan pita DNAnya dengan menggunakan kaca mata pelindung saat melakukan ekspos gel pada sinar UV. Hasil elektroforesis DNA ekstrak DNA genom Eucheuma sp. kemudian didokumentasikan dengan kamera.

\section{Amplifikasi Gen}

Proses amplifikasi gen dilakukan dengan menggunakan beberapa kombinasi primer COX2 dan $r b c L$ sebagai gen target amplifikasi. Tahap amplifikasi gen yang dilakukan pertama adalah membuat campuran reaksi yang diisi dalam tabung reaksi khusus untuk PCR. Tabung reaksi disentrifugasi selama 30 menit kemudian mesin PCR dinyalakan. Masing-masing tabung dimasukkan ke dalam PCR. Program Heater lid diatur pada suhu $99^{\circ} \mathrm{C}$. Program siklus yang akan digunakan dengan pengaturan suhu pre-denaturasi $95^{\circ} \mathrm{C}$ selama 6 menit, denaturasi $95^{\circ} \mathrm{C}$ selama 30 detik (35 siklus), annealing $52^{\circ} \mathrm{C}$ selama 30 detik, elongasi $72^{\circ} \mathrm{C}$ selama 30 detik, dan post-elongasi $72^{\circ} \mathrm{C}$ selama 10 menit. Hasil amplifikasi gen kemudian dielektroforesis untuk mengetahui keberhasilan gen yang diamplifikasi.

\section{HASIL DAN PEMBAHASAN}

\section{Ekstraksi DNA Eucheuma sp.}

Ekstraksi DNA Eucheuma sp. yang menggunakan metode CTAB yang dimodifikasi dari Doyle dan Doyle (1987) dalam penelitian ini menghasilkan hasil ekstraksi DNA yang masih tercampur dengan bahan lain sehingga membentuk gel. Hal ini diduga karena dalam prosedur ini menggunakan PVP dan $\beta$ mercaptoetanol berdasarkan metode Doyle dan Doyle (1987). Oleh sebab itu, dilakukan dengan menambahkan Vitamin C $500 \mathrm{gr}$ mengikuti prosedur dari Nugroho dkk., (2015) sehingga hasil ekstraksi DNA 
tidak tercampur dengan bahan lain dan tidak membentuk gel. Hasil ekstraksi DNA genomik yang bebas dari kontaminasi seperti protein, polisakarida, polifenol, lemak dan RNA dapat digunakan sebagai DNA template untuk proses analisis selanjutnya seperti amplifikasi dan sekuens DNA (Buckingham dan Flaws, 2007 dalam Hengkengbala, 2017). Prinsip dasar ekstraksi DNA adalah serangkaian proses untuk memisahkan DNA dari komponenkomponen lainnya. Hasil ekstraksi tersebut merupakan tahapan penting untuk langkah berikutnya dan harus dilakukan dengan baik dan bebas kontaminasi (Tenriulo $d k k$., 2001).

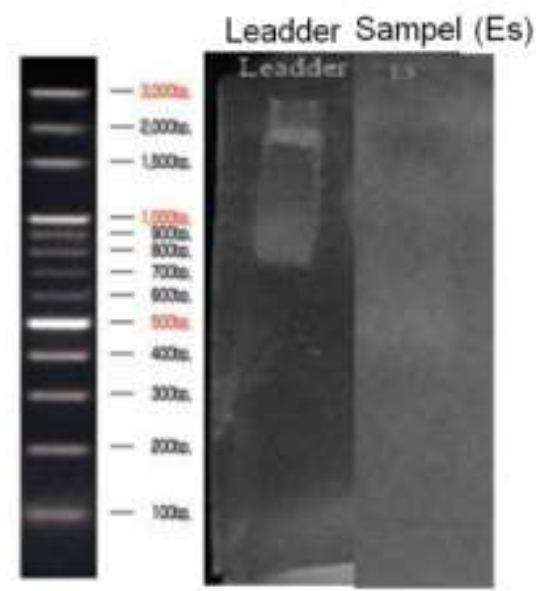

Gambar 1. Hasil Elektroforesis DNA Eucheuma sp. yang telah melalui proses modifikasi metode ekstraksi DNA menggunakan teknik CTAB.

Hasil visualisasi elektroforesis sampel DNA Eucheuma sp. dapat dilihat dari gambar 1. Hasil ini menunjukkan bahwa tidak terlihat pita DNA pada lintasan gel dari sampel yang digunakan. Hal ini disebabkan karena kurangnya DNA yang dihasilkan. Kurangnya DNA yang dihasilkan disebabkan oleh ketebalan dinding sel, sehingga sel tidak dapat terlisis dengan sempurna, walaupun dalam penelitian ini telah menggunakan nitrogen cair untuk melisis sel Eucheuma sp. Pada beberapa laporan penilitian menunjukkan keberhasilan penggunaan kit-kit komersial untuk mendapatkan ekstraksi genomik DNA biota laut (Sahari dkk., 2017; Wantania dkk., 2016; Wehantouw dkk., 2017 dan Peloa dkk., 2016). Namun penelitian yang dilakukan oleh Hengkengbala (2017) menunjukkan hasil yang berbeda dalam menggunakan kit komersial. Penggunaan kit tersebut tidak menunjukkan adanya keberhasilan dalam ekstraksi DNA genomik rumput laut jenis Eucheuma sp. Annisaqois, (2018) berhasil mengisolasi DNA dari rumput laut jenis Kappaphycus sp. dengan menggunakan ekstraksi buffer CTAB, akan tetapi, metode yang sama telah dilakukan dalam penelitian ini namun kurang menunjukkan keberhasilan isolasi DNA pada rumput laut jenis Eucheuma sp. Hal ini disebabkan perbedaan kandungan karaginan yang terkandung dalam Eucheuma sp. sehingga hasil yang didapatkan dalam penelitian juga berbeda. Sesuai dengan pernyataan Doyle dan Doyle, (1990) dalam Hengkengbala, (2017) bahwa prosedur yang berhasil digunakan untuk isolasi DNA pada satu kelompok tumbuhan atau alga seringkali gagal diaplikasikan untuk kelompok yang lainnya.

\section{Amplifikasi DNA Eucheuma sp.}

Hasil isolasi DNA kemudian diamplifikasi dengan menggunakan COX2 dengan pasangan primer Kcox2_F71 dan Kcox2_R671. DNA hasil isolasi juga diamplifikasi menggunakan gen $r b c L$ dengan 4 pasangan primer yakni primer $\mathrm{F}-7$ dan R-753, primer $\mathrm{F}-577$ dan R-rbcS, primer F-7 dan R-rbcS, primer F-577 dan R-753.

Hasil penelitian ini menunjukkan bahwa DNA gen rumput laut Eucheuma sp. berhasil diamplifikasi dengan menggunakan primer F-577 (for) dan R-753 (rev). Hal ini ditunjukkan adanya pita DNA pada lintasan gel (Gambar 2). Pita DNA berada pada posisi 1000-1200 bp. Panjang pita DNA (1000-1200 bp) menunjukkan ukuran DNA dari rumput laut. Sedangkan primer Kcox2_F71 (for) dan Kcox2_R671 (rev), primer F-7 (for) dan R-753 (rev), primer F577 (for) dan R-rbcS (rev), primer F-7 (for) dan R-rbcS (rev), tidak menunjukkan adanya pita DNA pada lintasan gel. Hal ini menunjukkan bahwa primer ini tidak dapat mengamplifikasi DNA rumput laut Eucheuma sp. dalam proses amplifikasi DNA rumput laut Eucheuma sp. 


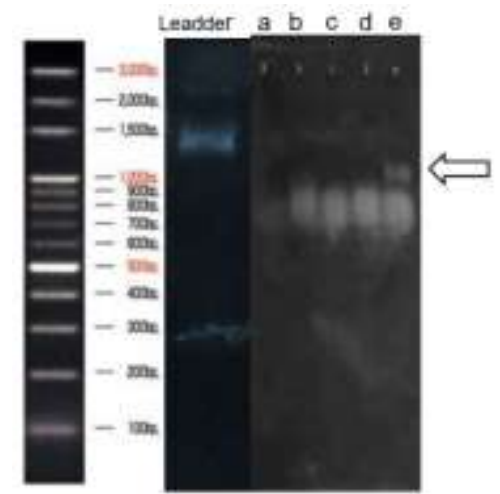

Gambar 2. Hasil amplifikasi gen COX2 dan rbcL: (a) Kcox2_F71 dan Kcox2_R671 (b) primer F-7 dan R753, (c) primer F-577 dan R-rbcS, (d) primer F-7 dan R-rbcS dan (e) primer F-577 dan R-753.

\section{KESIMPULAN}

Berdasarkan hasil penelitian yang telah didapatkan, maka dapat disimpulkan bahwa, rumput laut jenis Eucheuma sp. dapat dideteksi dengan menggunakan metode CTAB yang dimodifikasi walau belum optimal sehingga tidak terlihat adanya pita DNA pada lintasan gel dan pasangan primer F-577 (forward) dan R753 (reverse) dan berhasil mengamplifikasi DNA rumput laut Eucheuma sp. yang ditunjukkan adanya pita DNA pada lintasan gel dengan panjang basa 1000-1200 bp.

\section{DAFTAR PUSTAKA}

Allen, G.C., Flores-Vergara, M.A., Krasynanski, S., Kumar, S., Thompson, W.S. 2006. A modified protocol for rapid DNA isolation from plant tissues using cetyltrimethylammonium bromide. Nature Protocols, 1(5):2320-232

Anggadiredja, J. T. Zatnika, A. Purwoto, H dan Istini, S. 2010.Rumput Laut: Pembudidayaan, Pengolahan dan Pemasaran Komoditas Perikanan Potensial. Penebar Swadaya. Jakarta.

Anggraeni, S.R., Sudarsono dan D. Soedharma. 2008. Karakterisasi Genetika Rumput Laut Eucheuma sp. Dari Tiga Daerah Di Indonesia. Jurnal Bionatura. 10 (3):196-208.
Annisaqois, M., G. S. Gerung., S. Wullur., D. A. Sumilat., B. T. Wagey dan S. V. Mandagi. 2018. Analisis Molekuler DNA Alga Merah (RHODOPHYTA) Kappaphycus sp. 1:1.

Amaranggana. L., dan N. Wathoni. 2017. Manfaat Alga Merah (Rhodopyta) sebagai Sumber Obat dari Bahan Alam. Majalah Farmastika. 2:1.

Doyle dan Doyle, 1987. CTAB/Chloroformlsoamyl Alcohol DNA Extraction Protocol.

Gerung, G.S. 2001. Study on Indonesian Gracilariaceae. Ph.D. Tesis. Hokkaido University, Graduate School of Fisheries Science. Hokkaido, Japan. 312 hal.

Hengkengbala, I. R. 2017. Analisis Molekuler Beberapa Jenis Alga. Tesis. Fakultas Perikanan dan IImu Kelautan. UNSRAT.

Hudha, M. I., Sepdwiyanti, R., dan Sari, S. D. 2012. Ekstraksi Karaginan Dari Rumput Laut (Eucheuma spinosum) Dengan Variasi Suhu Pelarut Dan Waktu Operasi. 6:2.

Nugroho, K., Terryana, R.T., Lestari, P. 2015. Optimasi Metode Isolasi DNA pada Jatropha spp. Jurnal Agroteknologi. 5(2):15-22.

Peloa, A., S. Wullur dan C. A. Sinjal. Amplifikasi Gen Cytochrome Oxidase Subunit I (COI) Dari Sampel Sirip Ikan Hiu Dengan Menggunakan Beberapa Pasangan Primer. Jurnal Pesisir dan Laut Tropis. 1(1):37-42.

Sahari, J., J. Rimper dan S. Wullur. Identifikasi Molekul Rotifer Branchionus sp. Asal Perairan Tumpaan, Minahasa Selatan. Jurnal Pesisir dan Laut Tropis. 1(1): 56-61.

Tenriulo, A., Suryati, E., Parenrengi, A. dan Rosmita. 2001. Ekstraksi DNA Rumput Laut Kappaphycus alvarezii Dengan Metode Fenol Kloroform. Universitas Hasanuddin. Hal 6-10.

Wantania, L. L., E. Ginting dan S. Wullur. Isolasi Bakteri Simbion Dengan Spons Dari Perairan Tongkeina, Sulawesi Utara. Jurnal LPPM Bidang Sains dan Teknologi. 3(1) : 57-65.

Wehantouw, A., E. Ginting dan S. Wullur. Identifikasi Sirip Ikan Hiu Yang Didapat Dari Pengumpul Di Minahasa Tenggara Menggunakan DNA Barcode. Jurnal Pesisir dan Laut Tropis. 1(1): 62-68

Zuccarello, G.C., A.T. Cricthley, J. Smith, V. Sieber, G.B. Lhonneur dan J.A. West. 2006. Systematic and genetic variation in commercial Kappaphycus and Eucheuma (Solieriaceae, Rhodophyta). Journal of Applied Phycology. 